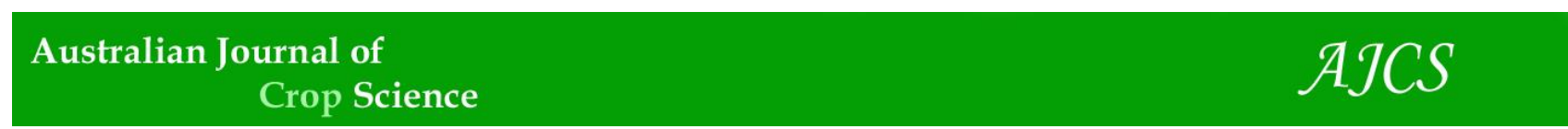

AJCS 11(11):1411-1417 (2017)

ISSN:1835-2707

doi: 10.21475/ajcs.17.11.11.pne539

\title{
Prediction of genetic gains and correlations in corn hybrids for silage
}

\section{Jocarla Ambrosim Crevelari ${ }^{1}$, Nayara Norrene Lacerda Durães ${ }^{1}$, Laila Cecília Ramos Bendia ${ }^{1}$, Alysson Jalles da Silva ${ }^{2}$ and Messias Gonzaga Pereira ${ }^{1}$}

${ }^{1}$ Universidade Estadual do Norte Fluminense Darcy Ribeiro, Avenida Alberto Lamego 2000, Parque Califórnia, CEP 28013-602, Campos dos Goytacazes, RJ, Brasil

${ }^{2}$ Universidade Estadual Paulista Júlio de Mesquita Filho, Faculdade de Ciências Agrárias e Veterinárias de Jaboticabal, Via de Acesso Prof. Paulo Donato Castellane s/n, Vila Industrial, CEP 14884900, Jaboticabal, SP, Brasil

*Corresponding author: jcrevelari@yahoo.com.br

\begin{abstract}
During the dry season the production of pastures dicreases. Usually, it makes the situation necessary to use corn silage as fibrous fodder source. The aim of this study was to develop corn hybrids for silage production, prioritizing hybrid combinations of the heterotic group 'DENT' to better understand the association between the evaluated traits and to optimize the selection process by using selection indices. Nineteen topcross hybrids and five controls were evaluated in a complete randomized block design with four and five replications in the agricultural years of 2013 and 2014. The following traits were evaluated: plant height, first ear height, stem diameter, yield at silage stage, ear yield with and without straw at silage stage, fresh mass yield, and proportion of grains in the fresh mass. The highest coefficients of correlation were obtained between yield and ear yield with straw $(\mathrm{r}=0.94 * *)$, and between ear yield with straw and fresh mass yield $(\mathrm{r}=0.89 * *)$. The Mulamba \& Mock selection index was used for prediction of genetic gains. For selection of the superior hybrids, the index resulted in higher estimates of predicted gains for yield at silage stage and fresh mass yield, with values of 6.13 and $4.46 \%$, respectively, using weights assigned. The use of selection indices allows simultaneous prediction of gains in the two main traits. Topcross hybrids presented high potential for silage yield in the North and Northwest Regions.
\end{abstract}

Keywords: Topcross; Tester; Index; Selection; Zea mays L.

Abbreviations: HIP_ Intrapopulational hybrid; $\mathrm{PH}_{-}$plant height; $\mathrm{EH}_{-}$ear height; $\mathrm{MD}_{-}$stem diameter; YS_ yield at silage stage; EYWS_ ear yield with straw at silage stage; EYWOS_ ear yield without straw at silage stage; FMY_ fresh mass yield; GFM_ proportion of grains in the fresh mass; $\mathrm{CV}_{\mathrm{e}_{-}}$coefficient of experimental variation; $\mathrm{CV}_{\mathrm{g}_{-}}$coefficient of genetic variation; Iv variation index; $\mathrm{h}^{2}{ }_{-}$mean heritability of the genotypes; $\hat{r}_{\text {gg }}$ Accuracy in genotypes selection; (A)_ year; (L)_ environment and (G)_ genotype.

\section{Introduction}

The exploration of milk and beef requires high yield of the herd throughout the year. In Brazil, supplementary feeding is required, especially in the fall and winter seasons, due to the seasonality of forage production. Thus, the use of forage during these seasons has increased each year (Gomes et al. 2004). Corn has key role among the forage plants used for supplementation due to its high fresh mass yield per hectare and for its good nutritional qualities (Melo et al. 1999). According to Paziani et al. (2009), corn is the standard crop for silage due to the tradition in its cultivation, the high yield and to its good nutritional value. Corn presents two heterotic groups: the 'DENT' and the 'FLINT'. The cross between genotypes of the heterotic group 'DENT' and 'FLINT' has been one of the most explored heterotic patterns in corn breeding programs (Borém and Miranda, 2005). Recent findings have indicated that ruminal digestibility of corn starch is variable due to genetic differences between hybrids. According to Philippeau et al. (1999), differences in grain vitreousness have been observed between varieties of 'DENT' and 'FLINT' corn. Varieties of the heterotic group 'DENT' present higher ruminal digestibility in relation to 'FLINT' corn. Therefore, the aim of this study was to identify heterotic intragroup hybrid combinations of group 'DENT', to obtain better quality products. Moraes et al. (2008) evaluated the nutritional value of the heterotic groups 'DENT' and 'FLINT' at three harvest stages for silage, and found that qualitatively, the group 'DENT' was superior at stages 1 and 2 , in relation to the 'FLINT' hybrid due to better digestibility and crude protein contents. Pereira et al. (2004) evaluated the ruminal degradability of 'FLINT' and 'DENT' texture corn grains at three different maturation stages and observed that the group 'DENT' and the group 'FLINT' presented $44.3 \%$ and $67.0 \%$ of vitreous endosperm, respectively. Ruminal degradation of dry matter in 24 hours was $63.3 \%$ for the group 'DENT', and of $52.4 \%$ for the group 'FLINT'. In plant breeding, studies are carried out with several traits simultaneously. Thus, the knowledge of the association between traits is very important, especially if the selection on one of them is problematic, due to the low heritability and/or to the difficult measurement and identification. According to Cruz et al. (2004), phenotypic correlation can be directly measured based on the measures of two traits of the population. This correlation has genetic and environmental causes. However, only the genetic cause involves association 
of inheritable nature; therefore, it can be used in breeding programs. Thus, in genetic studies, distinguishing and quantifying the degree of genetic and environmental association between traits is fundamental.

Selection indices are very useful tools in plant breeding programs, since they allow efficient selection of genotypes and prediction of genetic gain. According to Cruz et al. (2004), these indices are a multivariate technique that combines information on the number of agronomically important traits with the genetic properties of the studied population. The numerical value is created with the selection indices, and these values act as an additional, theoretical trait, resulting from the combination of certain traits selected by the breeders, on which simultaneous selection is desired. Mulamba \& Mock (1978) proposed the index based on the sum of ranks. This index ranks the genotypes, initially for each trait, by assigning higher absolute numbers to genotypes with superior performance. Once classified, the values assigned to each trait are summed, obtaining the 'sum of ranks', which indicates the classification of genotypes (Cruz and Carneiro, 2008). Given the above, the objective of this study was to develop corn hybrids for silage, prioritizing group 'DENT' hybrid combinations to better understand the association between the traits evaluated, and to optimize the selection process by the use of selection indices.

\section{Results and Discussion}

\section{Analysis of variance and genetic parameters}

Significant effect of treatments was observed, with $(\mathrm{P}<0.01)$ and $(\mathrm{P}<0.05)$ probability for all of the evaluated traits. These results demonstrate that genetic variability among genotypes, which enables successful selection of promising genotypes (Table 2).

The effects of years $\times$ environment $\times$ treatments interactions were significant only for $\mathrm{PH}$ and GFM. Significant interaction indicates that the response of the genotypes is not the same in different years and environments. Based on the results, the means of yield at silage stage and fresh mass yield were 7391 and $40381 \mathrm{~kg} \mathrm{ha}^{-1}$, respectively. Similar results were obtained in other studies. Paziani et al. (2009) evaluated agronomic traits in corn hybrids for silage, and obtained means of 6916 and $50470 \mathrm{~kg} \mathrm{ha}^{-1}$ of yield at silage stage and of fresh mass yield, respectively. In contrast, Santos et al. (2010) obtained mean of $33800 \mathrm{~kg} \mathrm{ha}^{-1}$ of FMY when evaluating corn varieties for silage. All traits presented heritability $\left(h^{2}\right)$ based on family means (above 51.23\%). Traits of greatest interest, i.e., YS, FMY and GFM, presented heritability percentage of $70.05 ; 75.04$, and $85.42 \%$, respectively. Thus, with high heritability values, selection can be carried out with great probability of success for all the traits of interest. Marcondes et al. (2012) considered heritability as the best parameter to infer the success of the improvement of a trait. According to the classification of Scapim et al. (1995), the coefficient of experimental variation $\left(\mathrm{CV}_{\mathrm{e})}\right.$ of the traits evaluated in this study was classified as low or high. Coefficients of variation ranged from $5.71 \%$ for $\mathrm{PH}$, to $22.47 \%$ for YS (Table 2). These coefficients of variation demonstrate acceptable experimental accuracy for all traits. Berilli et al. (2013) obtained coefficient of experimental variation and heritability of $20 \%$ and $56 \%$, respectively, for yield in the 11th reciprocal recurrent selection cycle among corn full-sib families. Faria et al. (2008) evaluated the effectiveness of reciprocal recurrent selection in popcorn hybrids, and obtained coefficient of experimental variation $\left(\mathrm{CV}_{\mathrm{e}}\right)$ and heritability $\left(\mathrm{h}^{2}\right)$ of $20.90 \%$ and $50.37 \%$ for yield, respectively. The coefficient of genetic variation $\left(\mathrm{CV}_{\mathrm{g}}\right)$ expresses the quantity of genetic variation, and allows the breeder to get a sense of the relative magnitude of changes that may be obtained by selection during a breeding program. Table 2 shows, in general, the traits that presented relatively high $\mathrm{CV}_{\mathrm{g}}$ values, highlighting EH, with $9.24 \%$.

Genetic parameter accuracy in genotypes selection is useful to identify environmental and genetic variation, both on a range of 0 to $100 \%$. Values above $70 \%$ are desirable in experiments of genotypes evaluation (Ramalho et al. 2012). In the present study, all the values were above 0.71 , which indicate the possibility of successful selection.

\section{Correlations estimates}

Table 3 shows the estimates of the coefficients of phenotypic Pearson's correlation between the eight studied traits. PH presented positive coefficient of correlation, and was significant at $(\mathrm{P}<0.01)$, with all the traits evaluated, except for MD and GFM.

Correlation between $\mathrm{PH}$ and $\mathrm{EH}$ was highly significant and positive $\left(r=0.81^{* *}\right)$, indicating that plant height increases concomitantly with the ear height.

The highest coefficients of correlations were observed between yield at silage stage and ear yield without straw at silage stage $(\mathrm{r}=0.94 * *)$, and between ear yield with straw at silage stage and fresh mass yield $\left(\mathrm{r}=0.89^{* *}\right)$. These results show strong positive association between YS, EYWS, EYWOS and FMY. According to Paziani et al. (2009), ear fractions presented correlation values $(0.41)$ with yield at silage stage.

$\mathrm{PH}, \mathrm{EH}, \mathrm{YS}, \mathrm{EYWS}$ and EYWOS showed the highest coefficients of correlation with FMY, with $\mathrm{r}=0.66 * * ; 0.66 * *$; $0.65 * * ; 0.89 * *$ and $0.65 * *$, respectively. Mendes et al. (2008) evaluated corn hybrids for silage production and obtained correlation coefficient $(0.63)$ between fresh mass yield and plant height. Paziani et al. (2009) observed positive correlation between plant height and fresh mass yield (0.25). In addition, Santos et al. (2002) observed positive correlation between plant height $(0.50)$ and height of the first ear insertion (0.51) with yield in corn hybrids. These correlations corroborate this study. In breeding programs, the knowledge of the correlations between traits that contribute to higher yield and fresh mass yield is crucial, since these traits facilitate the selection of favorable hybrids, and may guide the selection methodology. According to Gomes et al. (2004), the study on the relationship between different traits allows directing the selection. Therefore, the most regionally suitable hybrid can be used for fresh mass yield, when no specific information is found for corn hybrids for silage production. In addition, attention should be given to the yield at silage stage, yield of year with and without straw at silage stage and plant height, due to the high correlation between these traits with fresh mass yield.

\section{Estimates of genetic gains by selection index}

Table 4 shows the estimates of percentage gains predicted by the Mulamba \& Mock index (1978), using coefficient of genetic variation $\left(\mathrm{CV}_{\mathrm{g}}\right)$, variation index $\left(\mathrm{I}_{\mathrm{v}}\right)$, heritability $\left(\mathrm{h}^{2}\right)$, and economic weights were assigned (RW) considering that selection was carried out for the traits $\mathrm{PH}, \mathrm{EH}, \mathrm{MD}, \mathrm{YS}$, EYWS, EYWOS, FMY, and GFM.

Evaluation of economic weights used in the Mulamba and Mock selection index (1978) showed that the economic 


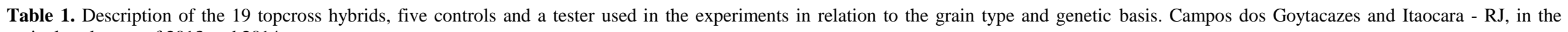
agricultural years of 2013 and 2014.

\begin{tabular}{|c|c|c|c|}
\hline Identification & Hybrids & Grain type & Genetic basis \\
\hline 1 & UENF-2194* & Dent & Lines \\
\hline 2 & UENF-2195* & Dent & Lines \\
\hline 3 & UENF-2199* & Dent & Lines \\
\hline 4 & UENF-2205* & Dent & Population \\
\hline 5 & UENF-2198* & Dent & Lines \\
\hline 6 & UENF-2203* & Dent & Population \\
\hline 7 & UENF-2192* & Dent & Lines \\
\hline 8 & UENF-2206* & Dent & Population \\
\hline 9 & UENF-2207* & Dent & Population \\
\hline 10 & UENF-2208* & Dent & Lines \\
\hline 11 & UENF-2209* & Dent & Lines \\
\hline 12 & UENF-2210* & Dent & Population \\
\hline 13 & UENF- 2200* & Dent & Population \\
\hline 14 & UENF-2202* & Dent & Population \\
\hline 15 & UENF-2201* & Dent & Population \\
\hline 16 & UENF-2204* & Dent & Population \\
\hline 17 & UENF-2193* & Dent & Lines \\
\hline 18 & UENF-2191* & Dent & Lines \\
\hline 19 & Piranão 13* & Dent & Population \\
\hline 20 & 'AG $1051^{* *}$, & Dent & Hybrid double \\
\hline 21 & UENF-2197** & Semi-dent & Lines \\
\hline 22 & UENF-2196** & Semi-dent & Lines \\
\hline 23 & ' $\mathrm{Br} 106^{* *}$ & Semi-dent & Population \\
\hline \multirow[t]{2}{*}{24} & 'UENF 506-11**' & Semi-dent & HIP \\
\hline & Piranão $12 * * *$ & Dent & Population \\
\hline
\end{tabular}

*Topcross hybrids; ** Controls; *** Tester. The genotypes 1 to 19,21 and 22 were crossed with Piranão 12.

Table 2. Summary of the analysis of variance of eight traits evaluated in corn hybrids for silage. Campos dos Goytacazes and Itaocara, RJ, in the agricultural years of 2013 and 2014.

\begin{tabular}{|c|c|c|c|c|c|c|c|c|c|}
\hline \multirow{2}{*}{$\mathrm{FV}$} & \multicolumn{3}{|c|}{ Mean squares ${ }^{1 /}$} & \multirow[b]{2}{*}{ MD } & \multirow[b]{2}{*}{ YS } & \multirow[b]{2}{*}{ EYWS } & \multirow[b]{2}{*}{ EYWOS } & \multirow[b]{2}{*}{ FMY } & \multirow[b]{2}{*}{ GFM } \\
\hline & GL & $\mathrm{PH}$ & EH & & & & & & \\
\hline Blocks (A x L) & 14 & 0.188 & 0.133 & 8.021 & 5984737.7 & 15059021.7 & 10538310.7 & 123982230 & 25.068 \\
\hline Year (A) & 1 & $32.441 * *$ & $17.631 * *$ & $1436.291 * *$ & $509867994.8 * *$ & $546158459.2 * *$ & $143693112.6 * *$ & 31605233025 ** & $631.039 * *$ \\
\hline Environment (L) & 1 & $1.047^{\mathrm{ns}}$ & $2.284^{\mathrm{ns}}$ & $1433.449 * *$ & $9633489.2^{\mathrm{ns}}$ & $364043024.9 * *$ & $124069333.0 * *$ & $144561082^{\text {ns }}$ & $10.266^{\mathrm{ns}}$ \\
\hline Genotype (G) & 23 & $0.417^{* *}$ & $0.346^{* *}$ & $23.757 * *$ & $11264083.1^{* *}$ & 25594943.4* & $16129997.2^{* *}$ & 319625050 ** & $53.001^{* *}$ \\
\hline$A \times G$ & 23 & $0.022^{\mathrm{ns}}$ & $0.021^{\mathrm{ns}}$ & $3.135^{\mathrm{ns}}$ & $3372879.7^{\text {ns }}$ & $12480892.1^{* *}$ & $5715658.5 * *$ & 79751456 ** & $7.726^{\mathrm{ns}}$ \\
\hline $\mathrm{L} \times \mathrm{G}$ & 23 & $0.025^{\mathrm{ns}}$ & $0.021^{\text {ns }}$ & $4.222^{\mathrm{ns}}$ & $1071661.9^{\mathrm{ns}}$ & $4516534.8^{\text {ns }}$ & $2069186.1^{\text {ns }}$ & $65910796^{\mathrm{ns}}$ & $12.076^{\mathrm{ns}}$ \\
\hline$A \times L$ & 1 & $3.271^{* *}$ & $3.472^{* * *}$ & $6.032^{\text {ns }}$ & $55199242.4 * *$ & $19798802.2^{\mathrm{ns}}$ & $8467401.4^{\text {ns }}$ & 793714634 ** & $27.922^{\mathrm{ns}}$ \\
\hline$A \times L \times G$ & 23 & $0.092^{* * *}$ & $0.021^{\mathrm{ns}}$ & $4.109^{\mathrm{ns}}$ & $3975892.5^{\text {ns }}$ & $8427765.4^{\text {ns }}$ & $4396733.3^{\text {ns }}$ & $58930597^{\text {ns }}$ & $15.723^{*}$ \\
\hline Error & 322 & 0.017 & 0.0138 & 3.245 & 2758815 & 5901885 & 3382490 & 45388796 & 8.338 \\
\hline Average & - & 2.28 & 1.46 & 24.32 & 7391 & 12889 & 9309 & 40381 & 18.72 \\
\hline $\mathrm{CV}_{\mathrm{e}}(\%)$ & - & 5.71 & 7.80 & 7.40 & 22.47 & 18.84 & 19.75 & 16.68 & 15.52 \\
\hline $\mathrm{CV}_{\mathrm{g}}(\%)$ & - & 6.53 & 9.24 & 4.42 & 9.01 & 6.66 & 8.22 & 9.09 & 8.52 \\
\hline $\mathrm{I}_{\mathrm{v}}$ & - & 1.14 & 1.18 & 0.60 & 0.40 & 0.35 & 0.41 & 0.54 & 0.55 \\
\hline$h^{2}$ & - & 94.87 & 93.81 & 86.80 & 70.05 & 51.23 & 64.56 & 75.04 & 85.42 \\
\hline$\hat{\mathrm{r} g g}$ & & 0.97 & 0.96 & 0.93 & 0.83 & 0.71 & 0.80 & 0.86 & 0.92 \\
\hline
\end{tabular}

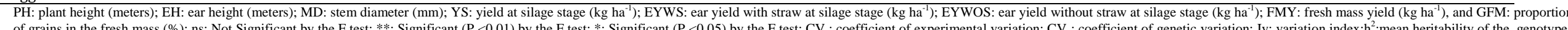

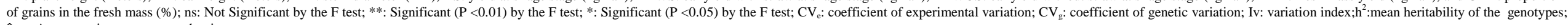
rgg: Accuracy in genotypes selection. 
Table 3. Estimates of the coefficients of phenotypic Pearson's correlations between eight traits of corn hybrids for silage. Campos dos Goytacazes and Itaocara, RJ, in the agricultural years of 2013 and 2014.

\begin{tabular}{|c|c|c|c|c|c|c|c|c|}
\hline Traits ${ }^{1 /}$ & $\mathrm{PH}$ & $\mathrm{EH}$ & MD & YS & EYWS & EYWOS & FMY & GFM \\
\hline $\mathrm{PH}$ & 1 & $0.81 * *$ & $-0.33^{\text {ns }}$ & $0.55 * *$ & $0.61 * *$ & $0.65 * *$ & $0.66^{* * *}$ & $-0.11^{\mathrm{ns}}$ \\
\hline $\mathrm{EH}$ & & 1 & $-0.21^{\mathrm{ns}}$ & $0.58 * *$ & $0.64 * *$ & $0.63 * *$ & $0.66^{* *}$ & $-0.05^{\mathrm{ns}}$ \\
\hline MD & & & 1 & $-0.02^{\mathrm{ns}}$ & $0.05^{\mathrm{ns}}$ & $-0.21^{\mathrm{ns}}$ & $0.20^{\mathrm{ns}}$ & $-0.24^{\mathrm{ns}}$ \\
\hline YS & & & & 1 & $0.82 * *$ & $0.94 * *$ & $0.65^{* *}$ & $0.42 *$ \\
\hline EYWS & & & & & 1 & $0.85^{* *}$ & $0.89 * *$ & $-0.07^{\mathrm{ns}}$ \\
\hline EYWOS & & & & & & 1 & $0.65^{* *}$ & $0.35 * *$ \\
\hline FMY & & & & & & & 1 & $-0.40^{\mathrm{ns}}$ \\
\hline GFM & & & & & & & & 1 \\
\hline
\end{tabular}

${ }_{1 /}$ PH: plant height (meters); EH: ear height (meters); MD: stem diameter (mm); YS: yield at silage stage $\left(\mathrm{kg} \mathrm{ha}^{-1}\right)$; EYWS: ear yield with straw at silage stage (kg ha $\left.{ }^{-1}\right)$; EYWOS: ear yield

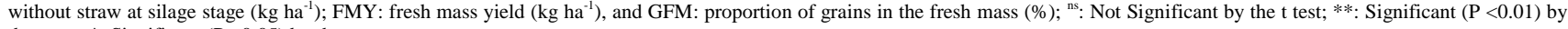
the $\mathrm{t}$ test; *: Significant $(\mathrm{P}<0.05)$ by the $\mathrm{t}$ test.

Table 4. Estimate of percentage gains based on differential selection, by simultaneous selection, in eight traits of corn hybrids for silage. Campos dos Goytacazes and Itaocara, RJ, in the agricultural years of 2013 and 2014.

\begin{tabular}{|c|c|c|c|c|}
\hline \multirow[b]{2}{*}{ Traits $^{1 /}$} & \multicolumn{4}{|c|}{ Mulamba \& Mock } \\
\hline & $\mathrm{CV}_{\mathrm{g}}$ & $\mathrm{I}_{\mathrm{V}}$ & $\mathrm{h}^{2}$ & RW \\
\hline $\mathrm{PH}$ & 1.69 & -4.30 & -0.82 & 2.15 \\
\hline $\mathrm{EH}$ & 1.56 & -5.34 & -0.54 & 3.17 \\
\hline MD & 0.03 & 2.98 & 1.09 & 0.21 \\
\hline YS & 5.95 & 0.51 & 4.19 & 6.13 \\
\hline EYWS & 2.91 & 0.05 & 2.49 & 3.52 \\
\hline EYWOS & 5.00 & -0.67 & 3.20 & 4.56 \\
\hline FMY & 2.86 & -0.73 & 2.57 & 4.46 \\
\hline GFM & 3.84 & 1.42 & 1.97 & 2.07 \\
\hline
\end{tabular}

Random weights used in the selection indexes: $\mathrm{CV}_{\mathrm{g}}=$ coefficient of genetic variation; $\mathrm{I}_{\mathrm{v}}=$ variation index; $\mathrm{h}^{2}=$ heritability; and $\mathrm{RW}=$ economic weights assigned (50; 50; 50; $100 ; 50$; 50; 100 and 100$).{ }^{1 /} \mathrm{PH}$ : plant height (meters); EH: ear height (meters); MD: stem diameter (mm); YS: yield at silage stage (kg ha $\left.{ }^{-1}\right)$; EYWS: ear yield with straw at silage stage (kg ha ${ }^{-1}$ ); EYWOS: ear yield without straw at silage stage $\left(\mathrm{kg} \mathrm{ha}^{-1}\right)$; FMY: fresh mass yield $\left(\mathrm{kg} \mathrm{ha}^{-1}\right)$, and GFM: proportion of grains in the fresh mass $(\%)$.

Table 5. Ranking and means of eight traits, evaluated in 10 corn hybrids for silage, selected by the Mulamba \& Mock index. Campos dos Goytacazes and Itaocara, RJ, in the agricultural years of 2013 and 2014.

\begin{tabular}{|c|c|c|c|c|c|c|c|c|c|}
\hline \multirow[b]{2}{*}{ Ranking } & \multirow[b]{2}{*}{ Hybrids } & \multicolumn{8}{|c|}{ Traits average } \\
\hline & & $\mathrm{PH}$ & $\mathrm{EH}$ & MD & YS & EYWS & EYWOS & FMY & GFM \\
\hline 1 & UENF 2210 & 2.54 & 1.62 & 24.00 & 8810 & 15156 & 11220 & 46345 & 19.34 \\
\hline 2 & UENF 2205 & 2.23 & 1.32 & 26.33 & 7802 & 14354 & 9433 & 45940 & 17.22 \\
\hline 3 & UENF 2197 & 2.16 & 1.54 & 25.51 & 7890 & 13651 & 9553 & 42704 & 18.52 \\
\hline 4 & AG 1051 & 2.25 & 1.41 & 23.42 & 8064 & 13234 & 10300 & 38077 & 21.48 \\
\hline 5 & UENF 2202 & 2.41 & 1.59 & 22.76 & 8415 & 13176 & 10411 & 39541 & 21.54 \\
\hline 6 & UENF 2191 & 2.25 & 1.39 & 25.23 & 7852 & 12862 & 9430 & 39667 & 20.15 \\
\hline 7 & UENF 2207 & 2.16 & 1.35 & 26.57 & 7449 & 13087 & 9074 & 41432 & 18.67 \\
\hline 8 & UENF 2201 & 2.43 & 1.57 & 23.32 & 7975 & 13880 & 10326 & 43145 & 18.75 \\
\hline 9 & UENF 2204 & 2.36 & 1.53 & 22.63 & 7924 & 13691 & 10199 & 43138 & 18.83 \\
\hline 10 & UENF 2208 & 2.58 & 1.80 & 24.13 & 8209 & 14659 & 9739 & 47848 & 17.30 \\
\hline
\end{tabular}

assigned weights provided the highest estimates of gains for the traits evaluated in the study.

The most significant genetic gains for yield at silage stage $(6.13 \%)$ and fresh mass yield $(4.46 \%)$ were obtained using the economic weights assigned (RW). The use of economic weights assigned allowed satisfactory gains not only for YS and FMY, but also for the other traits such as plant height $(\mathrm{PH})$, with magnitude of $2.15 \%$; ear height $(\mathrm{EH})$, with magnitude of $3.17 \%$; stem diameter (MD), with magnitude of $0.21 \%$; ear yield with straw at silage stage (EYWS), with magnitude of $3.52 \%$; ear yield without straw at silage stage (EYWOS), with magnitude of $4.56 \%$; and proportion of grains in the green mass (GFM), with magnitude of $2.07 \%$ (Table 4). Therefore, by application of Mulamba \& Mock selection index in genotypes selection gains for all traits are obtained. These gains are ideal since, for silage, corn hybrids should present means as high as possible for the traits evaluated in this study. According to Rangel et al. (2011), the Mulamba \& Mock index resulted in more appropriate proportional gains for yield, with values of $8.53 \%$, by using the random weights in the selection of superior popcorn progenies. The Mulamba \& Mock index also provided the highest magnitudes of predicted gains for most traits with the use of economic weights assigned in popcorn (Santos et al., 2007; Freitas Júnior et al., 2009; Freitas Júnior et al., 2013).
Candido et al. (2011), reported that the most appropriate proportional gains for the set of traits were obtained by the economic weights assigned with the use of the Mulamba \& Mock index in corn. Although the Mulamba \& Mock index allowed obtaining satisfactory gains for the studied traits by using economic weights assigned, based on the premise of Cruz (1990) in plant breeding, economic weights assigned are difficult to be established. As proposed by Cruz (1990), economic weights assigned could be estimated from the statistics of the experimental data. Thus, the coefficient of genotypic variation $\left(\mathrm{CV}_{\mathrm{g}}\right)$ is a good reference, since it is a dimensionless parameter and is directly proportional to the genetic variance. Despite the fact that the coefficient of genotypic variation favored the obtainment of positive gains for YS and FMY (5.95 and 2.86\%, respectively), these gains were lower when compared with those obtained by using the economic weights assigned. However, favorable percentage gains with good magnitudes were identified for EYWS, EYWOS and GFM (Table 4). The use of the variation index as economic weights provided lower percentage gains for yield at silage stage $(0.51 \%)$. However, MD, EYWS and GFM presented percentage gains of only $2.98 ; 0.05$, and $1.42 \%$ respectively. Estimates of gains for the traits $\mathrm{PH}$, EH, EYWOS and FMY were negative, which is not interesting for silage purposes. The use of heritability as economic weights 
was also not a convenient alternative to the use of the Mulamba \& Mock index. The percentage gains expected for YS and FMY and GFM were lower than those predicted using the economic weights assigned (Table 4). The gains were $4.19 ; 2.57$, and $1.97 \%$ for YS, FMY, and GFM, respectively. In addition, negative gains were observed for $\mathrm{PH}$ and EH. Since the objective of this work was the simultaneous improvement of $\mathrm{PH}, \mathrm{EH}, \mathrm{MD}$, YS, EYWS, EYWOS, FMY, and GFM, the use of economic weights that result in lower gains on the means of one of these traits is not recommended. The use of the genetic variation index and heritability as economic weights is not a good alternative for the selection of superior hybrids. The quality of grain and fiber fraction (stem, leaves, cobs, and straw) is determinant in the nutrition value of the ensiled material (Demarquilly, 1994). According to Beleze et al. (2003), selection of corn hybrids for silage production should be based on yield, dry matter, and other plant components, such as cob, stem, leaves and straw. According to Costa et al. (2000), greater proportions of ears in the material to be ensiled contribute to better forage quality.

Table 5 shows the ranking and the means of the best hybrids with the 10 highest estimates of gains by the Mulamba \& Mock index. Hybrids UENF 2210; UENF 2205; UENF 2197; AG 1051; UENF 2202; UENF 2191; UENF 2207; UENF 2201; UENF 2204, and UENF 2208 were the most promising, with significant values, and they are the 10 better-ranked hybrids for the traits PH, EH, MD, YS, EYWS, EYWOS, FMY, and GFM.

Oliveira (2004) evaluated corn cultivars for silage in Alfenas and Valencia, in 2002/2003 and obtained approximately $37.8 \mathrm{t}$ $\mathrm{ha}^{-1}$. Mendes et al. (2008) reported that yield and fresh mass yield were approximately $6140 \mathrm{~kg} \mathrm{ha}^{-1}$ and $31370 \mathrm{~kg} \mathrm{ha}^{-1}$, respectively. Selected topcross hybrids presented means higher than those obtained in the works abovementioned. Based on the results, the hybrids UENF 2210; UENF 2202 and UENF 2208 had on average YS higher than that of the control. On the other hand, for FMY, the hybrids UENF 2210; UENF 2205; UENF 2201; UENF 2204 and UENF 2208 were also superior to the controls. Therefore, the combinations of UENF 2202, UENF 2205, UENF 2208 and UENF 2210 had high performance for yield at silage stage and of fresh mass yield, which is key factor for silage quality.

\section{Materials and Methods}

\section{Plant materials}

The plant genotypes originated from the corn collection of the State University of Northern Rio de Janeiro. To obtain the topcross hybrids, 19 genotypes were selected, all of them belong to the heterotic group 'DENT.' Each genotype was crossed with a tester, Piranão 12 , which is a broad-based tester, also belong to the heterotic group 'DENT', to generate heterotic group 'DENT' topcross hybrids (Table 1). Topcross hybrids were obtained in isolated field at the Experimental Station of Ilha Barra do Pomba in Itaocara- RJ, located in the northwest region of the state of Rio de Janeiro. Each genotype was grown in $10.0 \mathrm{~m}$ rows, spaced $1.0 \mathrm{~m}$ between row, with five seeds per meter, totaling 50 plants per row, and spaced $0.20 \mathrm{~m}$ apart. At flowering stage, females were detasseled before the ears released the style-stigma to avoid undesired crosses. Thus, style-stigma received only the tester pollen. Harvest was carried out 120 days after sowing.

\section{Field experiments}

Evaluation trials of topcross hybrids were simultaneously conducted at the Escola Técnica Estadual Agrícola Antônio Sarlo, in Campos dos Goytacazes (Northern Rio de Janeiro), in November 2013 and 2014, and at the Estação Experimental da Ilha Barra do Pomba in Itaocara (Northwestern Rio de Janeiro), in December 2013 and 2014, constituting two sites and two years, totaly 4 environments.

The experiment consisted of randomized blocks design, with 24 treatments, 19 topcross hybrids, and five controls (BR106, AG 1051, UENF 506-11, UENF-2196, and UENF2197). Four and five replicates were used in the first and second year, respectively. In the first year, the experimental unit consisted of a $5.0 \mathrm{~m}$ row, spaced $1.0 \mathrm{~m}$ between rows, with 25 plants per plot, spaced $0.20 \mathrm{~m}$ apart. In the second year, each experimental unit consisted of one $8.0 \mathrm{~m}$ row, spaced $1.0 \mathrm{~m}$ between rows with 40 plants per plot, spaced $0.20 \mathrm{~m}$ part.

Three seeds per hole at $5 \mathrm{~cm}$ depth were used. At 21 days after emergence, thinning was carried out, leaving one plant per hole.

Sowing was carried out in conventional system. According to the soil analysis, fertilization of $400 \mathrm{~kg} \mathrm{ha}^{-1}$ of the formulated N P K 8-28-16 was applied. Afterwards, two topdressing fertilizations were applied: the first, at 30 days after planting, with $300 \mathrm{~kg} \mathrm{ha}^{-1} \mathrm{~N}$ P K 20-00-20; and the second, at 45 days after planting, with $200 \mathrm{~kg} \mathrm{ha}^{-1}$ urea. Cultural practices were performed as recommended for corn (Fancelli and Dourado Neto, 2000).

\section{Agronomic traits evaluated}

The agronomic traits evaluated in this study were: plant height $(\mathrm{PH})$, measured from the ground level to the tassel insertion node $(\mathrm{m})$; average height of the first ear insertion $(\mathrm{EH})$, measured from the ground level to the base of the upper ear in the stem (m); average diameter of the stem (MD), measured in the first internode above the plant's shoot (mm); ear yield with straw at silage stage (EYWS) $\left(\mathrm{kg} \mathrm{ha}^{-1}\right)$; ear yield without straw at silage stage (EYWOS) $\left(\mathrm{kg} \mathrm{ha}^{-1}\right)$; yield at silage stage (YS) $\left(\mathrm{kg} \mathrm{ha}^{-1}\right)$; fresh mass yield (FMY) (kg ha $\left.{ }^{1}\right)$; and proportion of grains in the fresh mass (GFM) (\%).

$\mathrm{PH}, \mathrm{EH}$ and MD were taken at random from six plants in the plot at 80 days after planting. EYWS, EYWOS, YS and FMY were measured at 90 days after planting, in 15 plants per plot (totaling $3.0 \mathrm{~m}$ of each row in the plot, in the first year of the experiment) and in 20 plants per plot (totaling 4.0 $\mathrm{m}$ of each row in the plot, in the second year of the experiment). The crop was harvested by cutting the plants at $20 \mathrm{~cm}$ from the soil, when the grains were at farinaceous stage. EYWS and EYWOS were obtained by weighing the grains with and without straw at silage stage. YS was obtained by weighing the threshed grain at silage stage, and the FMY was obtained by weighing the plants (leaf + stem + cob + ear straw + grain) of each harvest plot. GFM was obtained by the YS/ FMY ratio.

\section{Statistical analysis}

The joint analysis of variance was carried out according to the following statistical model:

$$
\begin{gathered}
Y_{i j k m}=\mu+G_{i}+A_{j}+L_{k}+(B / A) L_{j k m}+G A_{i j}+G L_{i k} \\
+A_{j k}+G A L_{i j k}+e_{i j k m}
\end{gathered}
$$


Where:

$\mathrm{Y}_{\mathrm{ijkm}}$ is the observation in the k-th environment, evaluated in the $\mathrm{i}$-th genotype and $\mathrm{j}$-th year and $\mathrm{m}$-th block; $\mu$ is the general constant of the trial; $G_{i}$ is the random effect of the genotypes (NID, $0, \sigma_{G}^{2}$ ); $A_{j}$ is the random effect if the year (NID, $\left.0, \sigma_{A}^{2}\right) ; L_{k}$ is the fixed effect of the environment; $\mathrm{GA}_{\mathrm{ij}}, \mathrm{GL}_{\mathrm{ik}}$ and $\mathrm{AL}_{\mathrm{jk}}$ are the effects of single interactions between genotype $\mathrm{x}$ year, genotype $\mathrm{x}$ environment, and environment $\mathrm{x}$ year ; $\mathrm{GAL}_{\mathrm{ijk}}$ is the effect of the triple interaction between genotype $\mathrm{x}$ year $\mathrm{x}$ environment; (B/ A) $\mathrm{L}_{\mathrm{jkm}}$ is the block effects within a year, within a environment (NID, 0, $\sigma_{b}^{2}$ ); $e_{i j k m}$ is the random error associated with the observation $Y_{i j k m}, e_{i j k m} \sim \operatorname{NID}\left(0, \sigma^{2}\right)$.

Correlations and estimates of gains with selection, using the selection index, were taken into account based on the average of the joint analysis, i.e., of the two sites and two years studied.

Predictions of gains with selection were obtained by the Mulamba \& Mock index (1978), with selection intensity of $41.66 \%$, corresponding to 10 superior hybrids to continue the breeding program. In the computational analysis, economic weights assigned $(50 ; 50 ; 50 ; 100 ; 50 ; 50 ; 100$ and 100) for each trait analyzed (PH, EH, MD, YS, EYWS, EYWOS, FMY, and GFM), respectively. Correlations and selection of superior hybrids based on the selection index were carried out using the SAS software - (SAS INSTITUTE INC, 2013).

\section{Conclusion}

Selection index allowed simultaneous prediction of gains in two main traits, YS and FMY, with gain percentage of 6.13 and $4.46 \%$, respectively. The selection of superior hybrid was possible due to the Mulamba \& Mock index, by means of economic weights assigned. The topcross hybrids UENF 2202, UENF 2205, UENF 2208, and UENF 2210 presented high potential for silage production in the North and Northwest Region of the state of Rio de Janeiro. The traits that better correlated with YS were EYWS and EYWOS, with coefficients of correlation of 0.82 and 0.94 , respectively. The traits PH, EH, YS, EYWS and EYWOS showed significant coefficient of correlation with FMY, with coefficients of $0.66,0.66,0.65,0.89$ and 0.65 , respectively.

\section{Acknowledgments}

We are grateful to UENF for granting scholarship and to FAPERJ for the financial support that made possible the implementation of field experiments.

\section{References}

Beleze JRF, Zeoula LM, Cecato U, Dian PHM, Martins EN, Facão AJS (2003) Avaliação de cinco híbridos de milho (Zea mays, L.) em diferentes estádios de maturação-produtividade, características morfológicas e correlações. R. Bras. Zootec. 32:529-537.

Berilli APCG, Pereira MG, Tindade RS, Costa FR (2013) Response to the selection in the $11^{\text {th }}$ cycle of reciprocal recurrent selection among full-sib families of maize. Acta Sci Agron. 35: 435-441.

Borém A, Miranda GV (2005) Melhoramento de plantas. Viçosa:UFV 4:525.

Candido LS, Andrade JAC, Garcia, FQ, Gonçalves LSA, Amaral Júnior AT (2011) Seleção de progênies de meiosirmãos do composto Isanão VF-1 de milho na safra e safrinha. Ciênc Rural. 41:947-953.
Costa C, Creste CR, Arrigoni MB, Silveira AC, Rosa GJM, Bicudo SJ (2000) Potencial para ensilagem, composição química e qualidade da silagem de milho com diferentes proporções de espigas. Acta Sci. 22:835-841.

Cruz CD (1990) Aplicação de algumas técnicas multivariadas no melhoramento de plantas. Tese (Doutorado em Genética e Melhoramento de Plantas) - Piracicaba SP, Escola Superior de Agricultura Luiz de Queiroz - ESALQ/USP, 188p.

Cruz, CD, Carneiro, PCS (2008) Modelos biométricos aplicados ao melhoramento genético. Viçosa:UFV 2:585.

Cruz CD, Regazzi AJ, Carneiro PCS (2004) Modelos biométricos aplicados ao melhoramento genético. Viçosa:UFV 1:480.

Demarquilly C (1994) Facteurs de variation de la valeur nutritive du mais ensilage. Prod Anim. 7:177-189.

Fancelli AL, Dourado Neto D (2000) Produção de milho. Guaíba: Agropecuária 1:360.

Faria VR, Viana JMS, Sobreira FM, Silva AC (2008) Seleção recorrente recíproca na obtenção de híbridos interpopulacionais de milho-pipoca. Pesq Agropec Bras. 43:1749-1755.

Freitas Júnior IL, Amaral Júnior AT, Viana AP, Pena GP, Cabral PS, Vittorazzi C, Silva TRC (2013) Ganho genético avaliado com índices de seleção e com REML/BLUP em milho de pipoca. Pesq Agropec Bras. 48:1464-1471.

Freitas Júnior SP, Amaral Júnior AT, Rangel RM, Viana AP (2009) Predição de ganhos genéticos na população de milho de pipoca UNB-2U sob seleção recorrente utilizando-se diferentes índices de seleção. Semin: Cien Agrar. 30:803-814 Gomes MS, Pinho RGV, Ramalho MAP, Ferreira DV, Brito AH (2004) Variabilidade genética em linhagens de milho nas características relacionadas com a produtividade de silagem. Pesq Agropec Bras. 39:879-885.

Marcondes MM, Neumann M, Marafon F, Rosário JG, Faria MV (2012) Aspectos do melhoramento genético de milho para produção de silagem. Appl Res Agrotec. 5:173-192.

Melo WMC, Pinho RGV, Carvalho MLM, Pinho EVRV (1999) Avaliação de cultivares de milho para produção de silagem na região de lavras - MG. Ciênc Agrotec. 23:31-39.

Mendes MC, Pinho RGV, Perreira MN, Faria Filho EM, Souza Filho AX (2008) Avaliação de híbridos de milho obtidos do cruzamento entre linhagens com diferentes níveis de degradabilidade da matéria seca. Bragantia. 67:285-297.

Moraes GJ, Costa C, Meirelles PRL, Oliveira k, Factori MA, Rosales LA, Santos TAB (2008) Produtividade e valor nutritivo das plantas de milho de textura dentada ou dura em três estádios de colheita para silagem. Bol Ind Anim. 65:155166.

Mulamba NN, Mock JJ (1978) Improvement of yield potential of the Eto Blanco maize (Zea mays L.) population by breeding for plant traits. Egypt J Gen Cytol. 7:40-51.

Oliveira JS (2004) Avaliação de cultivares de milho para silagem: resultados do ano agrícola 2002/2003. Circular Técnica 78. Juiz de Fora.12p.

Paziani SF, Duarte AP, Nussio LG, Gallo PB, Bittar CMM, Zopollatto M, Reco PC (2009) Características agronômicas e bromatológicas de híbridos de milho para produção de silagem. R Bras Zootec. 38:411-417.

Pereira MN, Von Pinho RG, Bruno RGS, Calestine GA (2004) Ruminal degradability of hard or soft texture corn grain at three maturity stages. Sci Agric. 61:358-363.

Philippeau C, Le Deschault de Moredon F, Michalet-Doreau B (1999) Relationship between ruminal starch degradation and the physical characteristics of corn grain. J Anim Sci. 77:238243. 
Ramalho MAP, Ferreira DF, Oliveira ACD (2012) Experimentação em genética e melhoramento de plantas. Lavras:UFLA. 2:305.

Rangel RM, Amaral Júnior AT, Gonçalves LS, Freitas Júnior SP, Candido LS (2011) Análise biométrica de ganhos por seleção em população de milho pipoca de quinto ciclo de seleção recorrente. Rev Ciênc Agron. 42:473-481.

SAS INSTITUTE INC, SAS, 9.4. Cary-NC, USA: SAS Institute, 2013.

Santos FS, Amaral Júnior AT, Freitas Júnior SP, Rangel RM, Pereira MG (2007) Predição de ganhos genéticos por índices de seleção na população de milho-pipoca UNB-2U sob seleção recorrente. Bragantia. 66:389-396.
Santos PG, Juliatti FC, Buiatti AL, Hamawaki OT (2002) Avaliação do desempenho agronômico de híbridos de milho em Uberlândia, MG. Pesq Agropec Bras. 37:597-602.

Santos RD, Pereira LGR, Neves ALA, Azevêdo JAG, Moraes AS, Costa CTF (2010) Características agronômicas de variedades de milho para produção de silagem. Acta Sci. 32: 367-373.

Scapim CA, Carvalho CGP, Cruz CD (1995) Uma proposta de classificação dos coeficientes de variação para a cultura do milho. Pesq Agropec Bras. 30:683-686. 